\title{
DNA Probes with Different Specificities from a Cloned 23S rRNA Gene of Micrococcus luteus
}

\author{
By ANGELA REGENSBURGER, WOLFGANG LUDWIG AND \\ KARL-HEINZ SCHLEIFER* \\ Lehrstuhl für Mikrobiologie, Technische Universität München, Arcisstr. 21, \\ D-8000 München 2, FRG
}

(Received 12 October 1987; revised 21 December 1987)

A 7500 bp Pst I restriction fragment of chromosomal DNA from Micrococcus luteus containing a 23S rRNA gene was cloned in vector pHE3 in E. coli RR 28 (the recombinant plasmid was designated pAR1). A recombinant phage (pAR5) hybridizing to all eubacteria tested was constructed by shotgun subcloning of the PstI fragment in phage M13mp8. Further subcloning of the fragments of the 23S rRNA gene in the vectors pTZ18R and pTZ19R using selected restriction sites of the gene enabled us to select cloned fragments of the 23S rRNA gene representing different specificities. Probes specific for Micrococcus luteus-Micrococcus lylae (pAR28), for the Arthrobacter-Micrococcus group (pAR27), for eubacteria (pAR5), and for the detection of eu- and archaebacteria (the so-called universal probe pAR17) were constructed. The specificity of each probe was analysed by dot hybridization to the chromosomal DNAs of representatives of most of the main phyla of eu- and archaebacteria.

\section{INTRODUCTION}

During the last few years specific DNA probes have gained importance in different fields, for example for the detection of bacterial and viral infections, the diagnosis of inherited diseases and genetic DNA fingerprinting for forensic applications. Specific probe hybridization techniques allow rapid analysis of pure and mixed cultures. It should also be possible to identify organisms that are difficult or impossible to cultivate. Ribosomal RNA genes are especially useful for the construction of specific DNA probes for various groups such as the Pseudomonas fluorescens group (Festl et al., 1986), legionellas (Edelstein, 1986), members of the genus Proteus (Haun \& Göbel, 1987) and mycoplasmas (Göbel et al., 1987).

To date the sequence comparison of $16 \mathrm{~S}$ rRNA is the best way to reveal close and distant phylogenetic relationships. Cataloguing and full sequence data and some $23 \mathrm{~S}$ rRNA total sequences have revealed that rRNA genes are composed of regions exhibiting different degrees of sequence conservation. Since these regions are longer and more distinct in the 23S rRNA than in the smaller 16S rRNA we chose a 23S rRNA gene for the construction of probes specific for close and distant relationships. Probes specific for Micrococcus luteus-Micrococcus lylae, for the Arthrobacter-Micrococcus group, for eubacteria and a universal probe have been constructed from a cloned 23S rRNA gene of $M$. luteus.

\section{METHODS}

Organisms and growth conditions. The strains used are listed in Table 2. Micrococci, arthrobacters, Bacillus subtilis, brevibacteria, cellulomonads, corynebacteria, Microbacterium lacticum and Oerskovia turbata were cultivated aerobically at $30^{\circ} \mathrm{C}$ in a medium containing $\left(\mathrm{g} \mathrm{l}^{-1}\right)$ : peptone (10); $\mathrm{NaCl}(8)$; yeast extract (5); glucose (5) (adjusted to $\mathrm{pH} 7 \cdot 5$ ). For cultivation on solid medium, $13 \mathrm{~g}$ agar $\mathrm{1}^{-1}$ was added.

Propionibacteria were grown anaerobically at $30^{\circ} \mathrm{C}$ in a medium containing $\left(\mathrm{g} \mathrm{l}^{-1}\right)$ : peptone (10); yeast extract (5); glucose (10) (adjusted to $\mathrm{pH} 7 \cdot 1$ ). Bifidobacteria were cultivated anaerobically at $37^{\circ} \mathrm{C}$ in a medium 
containing ( $\left.\mathrm{g}^{-1}\right)$ : peptone from meat (5); peptone from casein (5); yeast extract (1); meat extract (5); $\mathrm{NaH}_{2} \mathrm{PO}_{4}$ (2); Tween 80 (1); cysteine (5); glucose (5) ( $\mathrm{pH} \mathrm{7 \cdot 0).}$

Cells of Chondromyces apiculatus, Cytophaga lytica, 'Deinobacter' species, flavobacteria, Nannocystis exedens and Leucothrix mucor were gifts from H. Reichenbach (Braunschweig, FRG). Methanococcus vannielii cells were a gift from H. Märkl (München, FRG). Cells of Pyrococcus furiosus and Thermotoga maritima were gifts from K.-O. Stetter (Regensburg, FRG). Cells, chromosomal DNAs and filter-bound chromosomal DNAs of the remaining archaebacteria were gifts from W. Zillig and H. Klenk (Martinsried, FRG). Chromosomal DNAs of Nocardiopsis dassonvillei, Stomatococcus mucilaginosus, streptomycetes, and Streptosporangium roseum were gifts from E. Stackebrandt (Kiel, FRG).

Isolation and labelling of $r R N A$. The rRNAs were isolated according to the method of Stackebrandt et al. (1981) and labelled with $\left[\gamma^{-32}\right.$ P]ATP (New England Nuclear) using T4 polynucleotide kinase (BRL) as described previously (Schleifer et al., 1985).

Isolation of chromosomal DNA. This was done by the method of Marmur (1961) with the modifications described by Meyer \& Schleifer (1975, 1978).

Molecular cloning of $23 S$ rRNA genes. The identification, isolation and cloning of the 23S rDNA containing restriction fragments of chromosomal DNA from $M$. luteus in the vector pHE3 (Hennecke et al., 1982) in $E$. coli RR28 as well as the identification of the rDNA clones by Southern hybridization (Southern, 1975) was done as described previously (Schleifer et al., 1985). Subclones were constructed by using the phage vector M13mp8 (Messing \& Vieira, 1982) and E. coli JM101 (Yannisch-Perron et al., 1985) and the vectors pTZ18R and pTZ19R (Pharmacia) and E. coli JM83 (Yannisch-Perron et al., 1985), respectively.

Restriction enzymes, calf intestinal alkaline phosphatase and DNA ligase were purchased from BRL.

DNA sequencing. This was done according to Sanger et al. (1977). The sequencing primers were purchased from Boehringer, the M13 Sequencing Reagent Kit from BRL and the $\left[\alpha^{32}\right.$ P]dATP from New England Nuclear.

The isolation of single strand M13 phage DNA and the following sequencing reaction were done as described by Messing (1983). For the extraction of pTZ plasmid DNA, the rapid alkaline lysis procedure (Maniatis et al., 1982) and the double strand sequencing method as described by Chen \& Seeburg (1985) were used.

Labelling of the probes. The probes cloned in the sequencing vectors M13mp8 or pTZ were labelled with $\left[\alpha^{-32} \mathrm{P}\right] \mathrm{dATP}$ (New England Nuclear), by primer elongation according to the sequencing method (see above) in the absence of dideoxy nucleotides. The labelled DNA was separated from the free dATP by Elutip-d column chromatography (Schleicher and Schuell).

Hybridizations. For phage dot hybridization the phage supernatants were spotted onto a nylon membrane (ZetaProbe, BioRad) and baked for $2 \mathrm{~h}$ at $80^{\circ} \mathrm{C}$. Prehybridization was for $8 \mathrm{~h}$ at $50^{\circ} \mathrm{C}$ in $3 \times \mathrm{SSC}(1 \times \mathrm{SSC}$ is $0 \cdot 15 \mathrm{M}-$

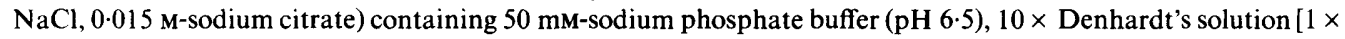
Denhardt's solution is $0.02 \%(\mathrm{w} / \mathrm{v})$ Ficoll, $0.02 \%(\mathrm{w} / \mathrm{v})$ polyvinylpyrrolidone, $0.02 \%(\mathrm{w} / \mathrm{v})$ bovine serum albumin), $0.1 \%(\mathrm{w} / \mathrm{v})$ SDS, $100 \mu \mathrm{g}$ sheared salmon sperm DNA ml ${ }^{-1}$ and $26 \%(\mathrm{v} / \mathrm{v})$ formamide. The DNA was denatured at $100{ }^{\circ} \mathrm{C}$ for $10 \mathrm{~min}$.

The hybridization to ${ }^{32} \mathrm{P}$-labelled 23S rRNA was done for $17 \mathrm{~h}$ under the same conditions with the exception that the concentration of the phosphate buffer ( $\mathrm{pH} \mathrm{6.5)}$ was reduced to $25 \mathrm{~mm}$ and $2 \times$ Denhardt's solution was used.

After hybridization, the filters were washed twice in $2 \times \mathrm{SSC}(\mathrm{pH} 7 \cdot 0$ ) containing $0.1 \%(\mathrm{w} / \mathrm{v})$ SDS for $15 \mathrm{~min}$ each and twice in $0.1 \times \mathrm{SSC}\left(\mathrm{pH} \mathrm{7.0)}\right.$ containing $0.1 \%(\mathrm{w} / \mathrm{v}) \mathrm{SDS}$ for $30 \mathrm{~min}$ each at $50^{\circ} \mathrm{C}$. Before rehybridization the probe DNA was removed from the membrane as recommended by the manufacturer.

For dot hybridization of spotted chromosomal DNA (Kafatos et al., 1979) $10 \mu \mathrm{g}$ samples of chromosomal DNA [denatured by alkali treatment according to Chen \& Seeburg (1985)] were spotted onto Zeta-Probe membrane using a Minifold (Schleicher and Schuell) filtration manifold and fixed by baking for $2 \mathrm{~h}$ at $80^{\circ} \mathrm{C}$. The prehybridizations and the hybridizations to the ${ }^{32} \mathrm{P}$-labelled probes were done under optimal conditions $\left(25^{\circ} \mathrm{C}\right.$ below the melting point of the probes) using the same solutions as for the dot hybridization (see above). For the calculation of the melting point the equation of Meinkoth \& Wahl (1984) was used.

\section{RESULTS}

Cloning of a $23 S$ rRNA gene

A recombinant plasmid designated pAR1 (Fig. 1) was obtained by cloning a $23 S$ rDNAcontaining, PstI restriction fragment from $M$. luteus DNA. It was characterized by restriction analysis and hybridization experiments with ${ }^{32} \mathrm{P}$-labelled 23S rRNA, 16S rRNA and 5S rRNA from $M$. luteus. The cloned fragment was 7500 base-pairs (bp) in length and contained a $23 \mathrm{~S}$ rRNA gene, a 5S rRNA gene and the major part of a 16S rRNA gene. 


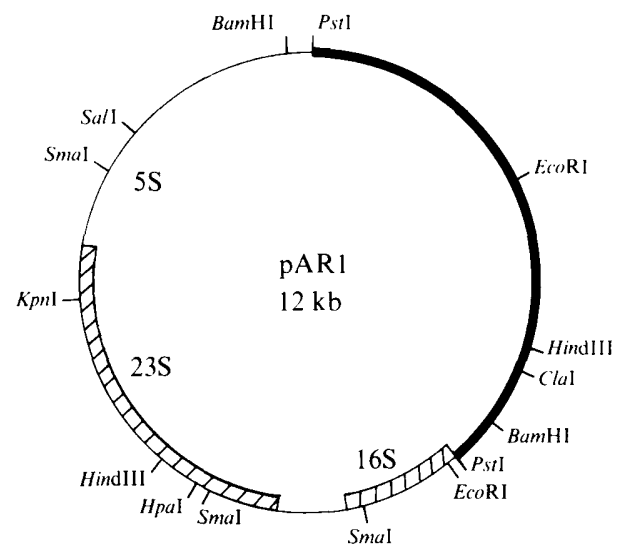

Fig. 1. Restriction map of the recombinant plasmid pAR1. The thick line represents vector pHE3 DNA; hatched lines represent cloned rRNA genes of $M$. luteus.

Subcloning of 23S rDNA fragments and screening of their specificity by phage dot hybridization

Plasmid pAR1 (Fig. 1) was digested with SmaI and the resulting fragments were separated by agarose gel electrophoresis. The $3.2 \mathrm{~kb}$ fragment containing most of the 23S rRNA gene was recovered from the gel and digested with various restriction enzymes ( $A c c \mathrm{I}, C f o \mathrm{I}, H p a \mathrm{II}, T a q \mathrm{I}$ and $\operatorname{Sau} 3 \mathrm{~A}$ ). The resulting $40-400 \mathrm{bp}$ fragments (length checked by agarose gel electrophoresis) were ligated with compatible phage vectors M13mp8 digested with $A c c \mathrm{I}$ or BamHI or $A c c \mathrm{I}$ and BamHI.

In dot hybridizations of the recombinant phage supernatants to ${ }^{32} \mathrm{P}$-labelled $23 \mathrm{~S}$ rRNAs of various prokaryotes, one of them hybridized to all $23 \mathrm{~S}$ rRNAs tested, with the exception of the archaebacterial rRNA. Sequence determination of the insertion of this recombinant phage (pAR5) revealed that it comprised two restriction fragments of the 23S rRNA gene, one TaqI fragment (115 bp) and one HpaII-CfoI fragment (67 bp) cloned in M13mp8 digested with AccI.

Subcloning of $23 S$ rDNA fragments and selection of specific probes by sequence comparisons

Subcloning of the cloned 23S rRNA gene of $M$. luteus in the vectors pTZ18R and pTZ19R and sequence determination of the cloned fragments enabled us to select cloned fragments with a definite degree of sequence conservation that might be appropriate for specific probes. This was elucidated by comparing the sequence of the $23 \mathrm{~S}$ rRNA gene of $M$. luteus (Regensburger $e t$ $a l ., 1988$ ) with published 23S rRNA sequences. Two cloned fragments representing variable regions of the gene designated pAR27 (127 bp) and pAR28 (99 bp) and one cloned fragment representing a highly conserved region of the gene (pAR17, $472 \mathrm{bp}$ ) were selected. Fig. 2 shows the sequences of the cloned fragments. The homology values between the probes and the corresponding regions of some published 23S rRNA gene sequences are shown in Table 1.

\section{Screening of the hybridization probes}

The specificity of the ${ }^{32} \mathrm{P}$-labelled hybridization probes was determined by dot hybridization (Kafatos et al., 1979) to the chromosomal DNAs of representatives of most of the main phyla of eubacteria and archaebacteria. The results are listed in Table 2. Fig. 3 shows autoradiograms of the same membrane after hybridization to different probes.

The recombinant phage pAR5 hybridized to the ${ }^{32} \mathrm{P}$-labelled 23S rRNAs of eubacteria but not to the archaebacterial ones and showed the same specificity when used as a labelled probe itself. The universal probe pAR17 hybridized to all eubacterial and archaebacterial chromosomal DNAs tested. pAR27 hybridized under optimal conditions to the chromosomal 


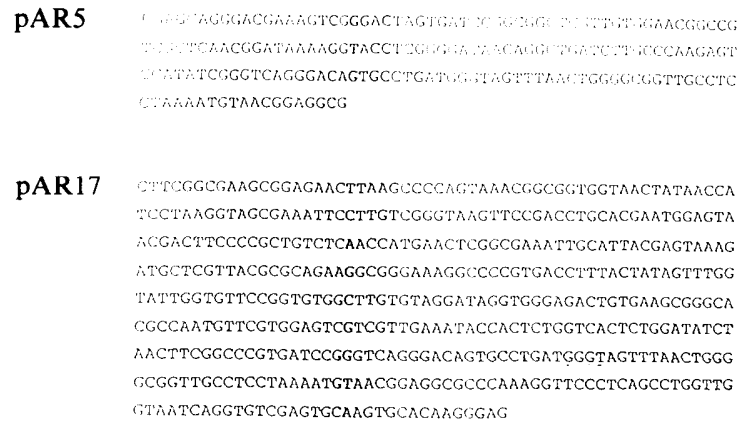

Fig. 2. Sequence of the insertions of the recombinant phage pAR5 and the recombinant plasmids pAR17, pAR27 and pAR28.
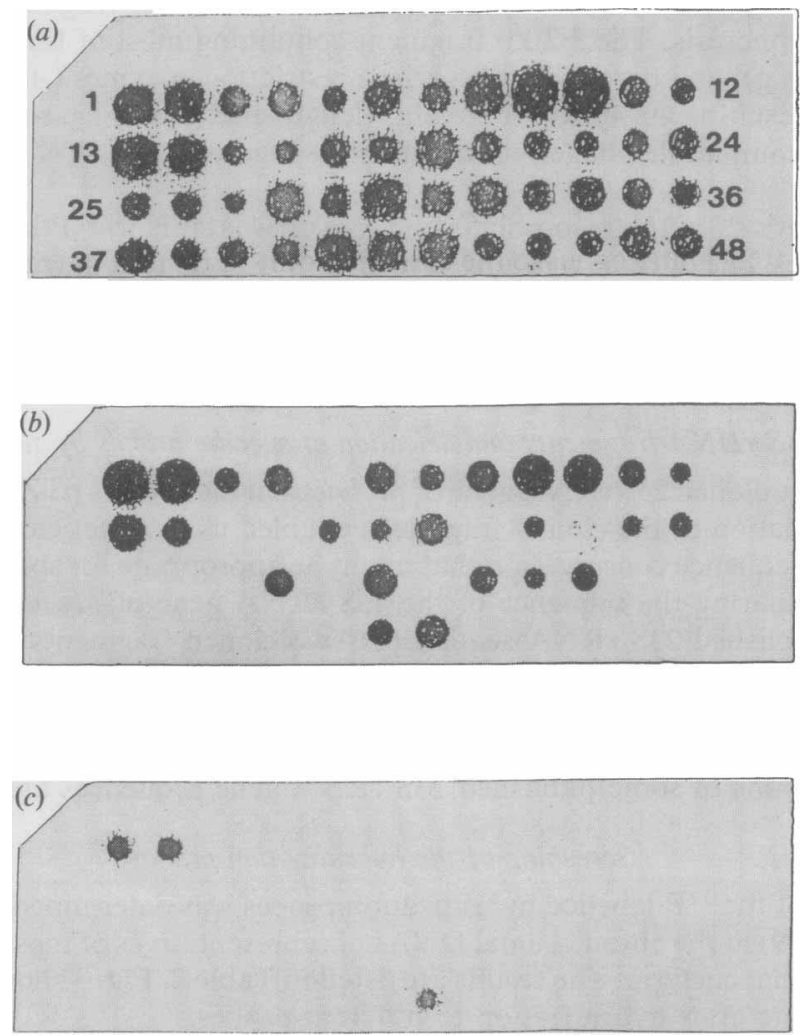

Fig. 3. Sequential hybridization of the same Zeta-Probe membrane containing DNAs from 48 organisms (numbers refer to Table 2) to ${ }^{32}$ P-labelled probes pAR17 (a), pAR27 (b) and pAR28 $(c)$. DNA of $E$. coli always gave a positive signal since the plasmid preparations contained trace-amounts of E. coli DNA. 
Table 1. Sequence homology between the probes and the corresponding regions of some $23 S$ rRNA genes

mc, Micrococcus luteus; bu, Bacillus subtilis (Green et al., 1985); bt, Bacillus stearothermophilus (Kop et al., 1984); an, Anacystis nidulans (Douglas \& Doolittle, 1984); ec, Escherichia coli (Brosius et al., 1980); mv, Methanococcus vannielii (Jarsch \& Böck, 1985).

\begin{tabular}{lllllll} 
& \multicolumn{6}{c}{ Homology values (\%) to the rDNA of: } \\
Probe & $\overbrace{\mathrm{mc}}$ & bu & bt & an & ec & mv \\
pAR17 & 100 & $82^{*}$ & $82^{*}$ & $78^{*}$ & $79^{*}$ & $76^{*}$ \\
pAR5 & 100 & 83 & 85 & 80 & 82 & 63 \\
pAR27 & 100 & 33 & 36 & 36 & 24 & 30 \\
pAR28 & 100 & 53 & 55 & 39 & 56 & 39
\end{tabular}

* A stretch of 93 bp showed homology values of $90-95 \%$.

DNAs of all micrococci and arthrobacters studied and also to DNAs of some other Grampositive bacteria. However, under stringent hybridization conditions (not shown in Tables 2 and Fig. 3) only DNAs of representatives of the genera Arthrobacter and Micrococcus gave a positive hybridization reaction with pAR27 and none of the other strains studied. pAR28 represents a very specific DNA probe that only hybridized to the DNAs of $M$. luteus and the closely related M. lylae.

\section{DISCUSSION}

Specific probes are required for definitive results in dot blot experiments. This could be expected of those regions of a 23S rRNA gene of which the sequence is not only homologous to the corresponding regions of the chromosomal DNAs of those bacteria that are to be detected, but also only moderately homologous to the corresponding regions of the chromosomal DNAs of other bacteria that are to be excluded. The hybridization conditions that we applied detected only organisms sharing at least $80 \%$ sequence homology. DNAs with lower homologies did not hybridize.

The first approach to obtain probes of various specificities was achieved by shotgun cloning of a cloned 23S rRNA gene and by selecting subcloned fragments with a certain specificity by phage dot hybridization. By this method a eubacterial specific DNA probe (pAR5) was obtained. Sequence determination and comparison with published 23S rRNA sequences revealed that the insertion in pAR5 represented a conservative region of the gene with a homology of more than $80 \%$ for eubacteria and only $63 \%$ for archaebacteria (Table 1 ). It only hybridized to DNA of eubacteria. To separate archaebacteria from eubacteria by a positive hybridization signal, a corresponding DNA probe specific for archaebacteria is still needed.

A direct subcloning of regions of the gene with a known degree of sequence conservation seemed to be more convenient for the construction of specific DNA probes than the random shotgun cloning technique used for the construction of pAR5. However a prerequisite for this approach is the knowledge of the sequence of the 23S rRNA gene of the organism from which these fragments are to be isolated and also the existence of usable restriction sites for cloning. We also stipulated that the region of the 23S rRNA gene should have a high degree of sequence homology (at least $80 \%$ ) to that group of organisms for which it should be specific.

The largest, coherent, universal stretch of the 23S rRNA gene is present in the insertion of the recombinant plasmid pAR 17 that produced positive hybridization signals with the chromosomal DNAs of all eubacteria and archaebacteria tested. Using this universal probe it was possible to estimate the amount of filter-bound chromosomal DNA that is accessible to a hybridization reaction. Therefore a correction of the hybridization results with the more specific probes could be done. False negative results, based upon failure of binding of the chromosomal DNA to the 
Table 2. Strains studied, their phylogenetic positions and their reactions with the ${ }^{32} P$-labelled probes under optimal hybridization conditions

\begin{tabular}{|c|c|c|c|c|c|c|c|c|}
\hline \multirow[b]{2}{*}{ No.* } & \multirow[b]{2}{*}{ Strain } & \multirow[b]{2}{*}{ Origin $\dagger$} & \multirow{2}{*}{$\begin{array}{c}S_{\mathrm{AB}} \text { of } \\
16 \mathrm{~S} \text { rRNA } \ddagger\end{array}$} & \multirow[b]{2}{*}{ Phylogeny§ } & \multicolumn{4}{|c|}{$\underbrace{\begin{array}{c}\text { Hybridization } \| \\
\text { pAR }\end{array}}_{\text {with pAR }}$} \\
\hline & & & & & 17 & 5 & 27 & 28 \\
\hline 1 & Micrococcus luteus & DSM $20030^{\mathrm{T}}$ & 1.00 & $\mathrm{Gm}+\mathrm{H}$ & + & + & + & + \\
\hline 2 & Micrococcus lylae & ATCC 17566 & 0.83 & $\mathrm{Gm}+\mathrm{H}$ & + & + & + & + \\
\hline 3 & Micrococcus varians & DSM $20033^{\mathrm{T}}$ & 0.75 & $\mathrm{Gm}+\mathrm{H}$ & + & + & + & - \\
\hline 4 & Micrococcus roseus & Back H15 & 0.71 & $\mathrm{Gm}+\mathrm{H}$ & + & + & + & - \\
\hline 5 & Micrococcus agilis & CCM 1744 & ND & $\mathrm{Gm}+\mathrm{H}$ & + & + & $(+)$ & - \\
\hline 6 & Arthrobacter globiformis & DSM $20124^{\mathrm{T}}$ & 0.77 & $\mathrm{Gm}+\mathbf{H}$ & + & + & + & - \\
\hline 7 & Arthrobacter ureafaciens & DSM $20126^{\top}$ & ND & $\mathrm{Gm}+\mathrm{H}$ & + & + & + & - \\
\hline 8 & Arthrobacter pascens & DSM $20545^{\mathrm{T}}$ & ND & $\mathrm{Gm}+\mathrm{H}$ & + & + & + & - \\
\hline 9 & Arthrobacter citreus & DSM $20133^{\mathrm{T}}$ & 0.71 & $\mathrm{Gm}+\mathrm{H}$ & + & + & + & - \\
\hline 10 & Arthrobacter citreus & ATCC 21348 & 0.71 & $\mathrm{Gm}+\mathrm{H}$ & + & + & + & - \\
\hline 11 & Arthrobacter atrocyaneus & DSM $20127^{\mathrm{T}}$ & 0.73 & $\mathrm{Gm}+\mathbf{H}$ & + & + & + & - \\
\hline 12 & Micrococcus kristinae & ATCC 27570 & ND & $\mathrm{Gm}+\mathrm{H}$ & + & + & + & - \\
\hline 13 & $\begin{array}{l}\text { Micrococcus } \\
\text { nishinomiyaensis }\end{array}$ & DSM $20448^{\mathrm{T}}$ & 0.68 & $\mathrm{Gm}+\mathrm{H}$ & + & + & + & - \\
\hline 14 & Cellulomonas flavigena & DSM $20109^{\mathrm{T}}$ & 0.62 & $\mathrm{Gm}+\mathrm{H}$ & + & + & + & - \\
\hline 15 & Cellulomonas flavigena & DSM $20109^{\mathrm{T}}$ & 0.62 & $\mathrm{Gm}+\mathrm{H}$ & + & + & - & - \\
\hline 16 & Cellulomonas biazotea & DSM $10112^{\mathrm{T}}$ & ND & $\mathrm{Gm}+\mathrm{H}$ & + & + & - & - \\
\hline 17 & Oerskovia turbata & NCIB 10585 & 0.68 & $\mathrm{Gm}+\mathbf{H}$ & + & + & + & - \\
\hline 18 & Cellulomonas cartae & DSM $20106^{\mathrm{T}}$ & ND & $\mathrm{Gm}+\mathrm{H}$ & + & + & + & - \\
\hline 19 & Brevibacterium linens & DSM 20158 & 0.62 & $\mathrm{Gm}+\mathrm{H}$ & + & + & + & - \\
\hline 20 & Microbacterium lacticum & DSM $20427^{\mathrm{T}}$ & 0.58 & $\mathrm{Gm}+\mathrm{H}$ & + & + & - & - \\
\hline 21 & Brevibacterium imperiale & DSM $20530^{\top}$ & ND & $\mathrm{Gm}+\mathrm{H}$ & + & + & + & - \\
\hline 22 & Corynebacterium betae & DSM 20141 & 0.64 & $\mathrm{Gm}+\mathrm{H}$ & + & + & - & - \\
\hline 23 & $\begin{array}{l}\text { Corynebacterium } \\
\text { michiganense }\end{array}$ & DSM 20134 & ND & $\mathrm{Gm}+\mathrm{H}$ & + & + & + & - \\
\hline 24 & Arthrobacter simplex & DSM $20130^{\mathrm{T}}$ & 0.55 & $\mathrm{Gm}+\mathrm{H}$ & + & + & + & - \\
\hline 25 & $\begin{array}{l}\text { Corynebacterium } \\
\text { glutamicum }\end{array}$ & DSM $20300^{\mathrm{T}}$ & 0.52 & $\mathrm{Gm}+\mathrm{H}$ & + & + & - & - \\
\hline 26 & $\begin{array}{l}\text { Brevibacterium } \\
\text { ketoglutamicum }\end{array}$ & ATCC 15587 & 0.55 & $\mathrm{Gm}+\mathrm{H}$ & + & + & - & - \\
\hline 27 & Corynebacterium fascians & DSM 20131 & 0.60 & $\mathrm{Gm}+\mathrm{H}$ & + & + & - & - \\
\hline 28 & Kitasatoa nagasakiensis & DSM $43361^{\mathrm{T}}$ & ND & $\mathrm{Gm}+\mathrm{H}$ & + & + & + & - \\
\hline 29 & Nocardiopsis dassonvillei & DSM $43111^{\mathrm{T}}$ & ND & $\mathrm{Gm}+\mathrm{H}$ & + & + & - & - \\
\hline 30 & $\begin{array}{c}\text { Stomatococcus } \\
\text { mucilaginosus }\end{array}$ & DSM 20445 & $0 \cdot 67$ & $\mathrm{Gm}+\mathrm{H}$ & + & + & + & - \\
\hline 31 & Streptomyces 'alborubidus' & DSM 40465 & ND & $\mathrm{Gm}+\mathrm{H}$ & + & + & - & - \\
\hline 32 & 'Streptomyces' salmonicida & DSM 40472 & ND & $\mathrm{Gm}+\mathrm{H}$ & + & + & + & - \\
\hline 33 & Streptomyces capreolus & DSM 40225 & ND & $\mathrm{Gm}+\mathrm{H}$ & + & + & + & - \\
\hline 34 & Streptosporangium roseum & DSM $43021^{\mathrm{T}}$ & 0.55 & $\mathrm{Gm}+\mathrm{H}$ & + & + & + & - \\
\hline 35 & $\begin{array}{l}\text { Propionibacterium } \\
\text { freudenreichii }\end{array}$ & DSM $20271^{\mathrm{T}}$ & 0.47 & $\mathrm{Gm}+\mathrm{H}$ & + & + & - & - \\
\hline 36 & $\begin{array}{l}\text { Propionibacterium } \\
\text { acidi-propionici }\end{array}$ & DSM 20272 & ND & $\mathrm{Gm}+\mathbf{H}$ & + & + & - & - \\
\hline 37 & Bifidobacterium bifidum & DSM $20456^{\mathrm{T}}$ & 0.41 & $\mathrm{Gm}+\mathrm{H}$ & + & + & - & - \\
\hline 38 & Bifidobacterium infantis & DSM $20088^{\mathrm{T}}$ & ND & $\mathrm{Gm}+\mathrm{H}$ & t & + & - & -- \\
\hline 39 & $\begin{array}{l}\text { Bifidobacterium } \\
\text { adolescentis }\end{array}$ & DSM $20083^{T}$ & ND & $\mathrm{Gm}+\mathrm{H}$ & + & + & - & - \\
\hline 40 & Bacillus subtilis & DSM $10^{\mathrm{T}}$ & 0.36 & $\mathrm{Gm}+\mathrm{L}$ & + & + & - & - \\
\hline 41 & Staphylococcus aureus & ATCC $12600^{\mathrm{T}}$ & 0.33 & $\mathrm{Gm}+\mathrm{L}$ & + & + & - & - \\
\hline 42 & Streptococcus pyogenes & NCTC $8198^{\mathrm{T}}$ & $0 \cdot 30$ & $\mathrm{Gm}+\mathrm{L}$ & + & + & $(+)$ & - \\
\hline 43 & Escherichia coli & DSM $30083^{\mathrm{T}}$ & 0.23 & PURC & + & + & + & + \\
\hline 44 & Ruminobacter amylophilus & DSM 1361 & 0.21 & PURC & + & + & - & - \\
\hline 45 & Enterobacter aerogenes & DSM $30053^{\mathrm{T}}$ & 0.21 & PURC & + & + & - & - \\
\hline 46 & Leucothrix mucor & DSM $2157^{\mathrm{T}}$ & 0.22 & & + & + & - & - \\
\hline 47 & Rhodobacter capsulatus & DSM $1710^{\mathrm{T}}$ & 0.22 & PURA & + & + & - & - \\
\hline 48 & Alteromonas putrefaciens & DSM 50426 & 0.21 & PURC & + & + & - & - \\
\hline 49 & Proteus mirabilis & DSM 788 & 0.21 & PURC & + & + & - & - \\
\hline 50 & Chondromyces apiculatus & DSM 436 & ND & PURD & + & + & - & - \\
\hline
\end{tabular}


Table 2. Continued

\begin{tabular}{|c|c|c|c|c|c|c|c|c|}
\hline \multirow[b]{2}{*}{ No.* } & \multirow[b]{2}{*}{ Strain } & \multirow[b]{2}{*}{ Origin $†$} & \multirow{2}{*}{$\begin{array}{c}S_{\mathrm{AB}} \text { of } \\
16 \mathrm{~S} \text { rRNA }\end{array}$} & \multirow[b]{2}{*}{ Phylogeny§ } & \multicolumn{4}{|c|}{ with pAR } \\
\hline & & & & & 17 & 5 & 27 & 28 \\
\hline 51 & Nannocystis exedens & DSM 71 & $0 \cdot 25$ & & + & + & - & - \\
\hline 52 & Flavobacterium breve & DSM 30096 & $0 \cdot 27$ & CFB & + & + & - & - \\
\hline 53 & Flavobacterium ferrugineum & DSM $30193^{T}$ & ND & CFB & + & + & - & - \\
\hline 54 & Cytophaga lytica & DSM $2039^{T}$ & 0.24 & CFB & + & + & - & - \\
\hline 55 & 'Deinobacter' sp. $\mid$ & R 5004 & 0.19 & RD & + & + & - & - \\
\hline 56 & Herpetosiphon aurantiacus & ATCC $23779^{\top}$ & $0 \cdot 18$ & $\mathrm{CX}$ & + & + & - & - \\
\hline 57 & Thermotoga maritima & DSM $3109^{\mathrm{T}}$ & ND & & + & + & - & - \\
\hline 58 & Methanococcus vannielii & DSM $1224^{\mathrm{T}}$ & 0.07 & ARC & + & - & - & - \\
\hline 59 & $\begin{array}{l}\text { Methanococcus } \\
\text { 'thermolithotrophicus' }\end{array}$ & DSM 2095 & ND & ARC & + & - & - & - \\
\hline 60 & Thermoproteus tenax & DSM $2978^{\mathrm{T}}$ & $0 \cdot 10$ & ARC & $(+)$ & - & - & - \\
\hline 61 & Desulfurococcus mobilis & DSM 2475 & ND & $\mathrm{ARC}$ & $(+)$ & - & - & - \\
\hline 62 & Thermococcus celer & DSM 2161 & ND & ARC & $(+)$ & - & - & - \\
\hline 63 & Pyrococcus furiosus & Stetter & ND & ARC & + & - & - & - \\
\hline 64 & Desulfurococcus mucosus & DSM 2162 & ND & ARC & $(+)$ & ND & ND & ND \\
\hline
\end{tabular}

* Numbers refer to Fig. 3.

+ ATCC, American Type Culture Collection, Rockville, Md, USA; Back, Weihenstephan, FRG; CCM, Czechoslovak Collection of Microorganisms, Brno, Czechoslovakia; DSM, Deutsche Sammlung von Mikroorganismen, Göttingen, FRG; NCIB, National Collection of Industrial Bacteria, Aberdeen, UK ; NCTC, National Collection of Type Cultures, London, UK; R, H. Reichenbach, Braunschweig, FRG; Stetter, K. O. Stetter, Regensburg, FRG; T, type strain.

$\ddagger S_{\mathrm{AB}}$ values relate to $M$. luteus. References: Stackebrandt \& Schleifer (1984); Ludwig et al. (1985); Ludwig (1981); E. Stackebrandt (personal communication); Woese et al. (1985); C. R. Woese (personal communication). ND, Not determined.

$\S$ Abbreviations according to Woese et al. (1985): Gm +, Gram-positive eubacteria; $\mathrm{L}$, low $\mathrm{G}+\mathrm{C}$ subdivision H, high G + C subdivision; PUR, purple bacteria and relatives, A, B, C and D, alpha, beta, gamma and delta (Fowler et al., 1986) subdivisions, respectively; CFB, flavobacteria and cytophagas; CY, cyanobacteria; CX, green nonsulphur bacteria and relatives; $R D$, radioresistant micrococci; ARC, archaebacteria.

$\|(+)$, Weakly positive; ND, not determined.

Tा Radioresistant rods related to Deinococcus species (H. Reichenbach, W. Ludwig and E. Stackebrandt, unpublished results).

filter or inaccessibility to a hybridization reaction, were excluded by control hybridizations using pAR17. This universal probe can also be used for screening for 23S rRNA genes, thus making the difficult isolation of the homologous $23 \mathrm{~S}$ rRNAs unnecessary.

The plasmid pAR27 not only hybridized under optimal conditions to the DNAs of all representatives of the genera Arthrobacter and Micrococcus that were studied, but also to two brevibacteria, two cellulomonads, Corynebacterium michiganense, Stomatococcus mucilaginosus, a few streptomyces and even Streptococcus pyogenes. However, the reactions clearly depended on the hybridization conditions applied. Stringent conditions $\left(20^{\circ} \mathrm{C}\right.$ below the melting point of the probe) resulted in increased specificity. In this case only the chromosomal DNAs of closely related bacteria belonging to the genera Arthrobacter and Micrococcus $\left(S_{\mathrm{AB}}>0.7\right)$ hybridized to the probe (data not shown).

The DNA probe pAR28 hybridized exclusively to the chromosomal DNAs of $M$. luteus and M. lylae.

23S RNA genes are, as the results of the present study show, a reservoir for the construction of DNA probes of various specificities. It has been demonstrated that it is possible to isolate not only DNA probes specific for closely related bacteria $\left(S_{\mathrm{AB}}>0.83\right)$ but also for distantly related organisms $\left(S_{\mathrm{AB}} 0 \cdot 1\right.$ and $\left.0 \cdot 2\right)$.

We are grateful to Drs Klenk, Märkl, Reichenbach, Stackebrandt, Stetter and Zillig for providing us with cells or DNAs from various organisms. This work was sponsored by grants from Deutsche Forschungsgemeinschaft and Fonds der Chemischen Industrie. 


\section{REFERENCES}

Brosius, J., Dull, T. J. \& Noller, H. F. (1980). Complete nucleotide sequence of a $23 \mathrm{~S}$ ribosomal RNA gene from Escherichia coli. Proceedings of the National Academy of Sciences of the United States of America 77, 201-204.

Chen, E. Y. \& Seeburg, P. H. (1985). Supercoiled sequencing: a fast and simple method for sequencing plasmid DNA. DNA 4, 165-170.

Douglas, S. E. \& Doolittle, W. F. (1984). Complete nucleotide sequence of the 23S rRNA gene of the cyanobacterium Anacystis nidulans. Nucleic Acids Research 12, 3373-3386.

EDELSTEIN, P. H. (1986). Evaluation of the Gen-probe DNA probe for the detection of legionellae in culture. Journal of Clinical Microbiology 23, 481-484.

Festl, H., Ludwig, W. \& Schleifer, K. H. (1986). DNA hybridization probe for the Pseudomonas fluorescens group. Applied and Environmental Microbiology 52, 1190-1194.

Fowler, V. J., Widdel, F., Pfennig, N., Woese, C. R. \& Stackebrandt, E. (1986). Phylogenetic relationships of sulfate- and sulfur-reducing eubacteria. Systematic and Applied Microbiology 8, 32-41.

Göbel, U. B., Geiser, A. \& Stanbridge, E. J. (1987). Oligonucleotide probes complementary to variable regions of ribosomal RNA discriminate between Mycoplasma species. Journal of General Microbiology 133, 1969-1974.

Green, C. J., Stewart, G. C., Hollis, M. A., Vold, B. S. \& BoTT, K. F. (1985). Nucleotide sequence of the Bacillus subtilis ribosomal RNA operon $r r n B$. Gene 37, 261-266.

HaUn, G. \& GöBel, U. (1987). Oligonucleotide probes for genus-, species- and subspecies-specific identification of representatives of the genus Proteus. FEMS Microbiology Letters 43, 187-193.

Hennecke, H., Günther, I. \& Binder, F. (1982). A novel cloning vector for the direct selection of recombinant DNA in Escherichia coli. Gene 19, 231234.

JARSCH, M. \& BöcK, A. (1985). Sequence of the 23S rRNA gene from the archaebacterium Methanococcus vannielii: evolutionary and functional implications. Molecular and General Genetics 200, 305-312.

Kafatos, F. C., Jones, C. W. \& Efstradiadis, A. (1979). Determination of nucleic acid sequence homologies and relative concentrations by a dot hybridization procedure. Nucleic Acids Research 7 , $1541-1552$.

Kop, J., Wheaton, V., Gupta, R., Woese, C. R. \& Noller, H. F. (1984). Complete nucleotide sequence of a $23 \mathrm{~S}$ ribosomal RNA gene from Bacillus stearothermophilus. DNA 3, 347-357.

LudwiG, W. (1981). Eine vereinfachte Methode zur Sequenzierung ribosomaler RNS und ihre Bedeutung für die Ableitung phylogenetischer Beziehungen von Mikroorganismen. PhD thesis, Technische Universität München, FRG.

Ludwig, W., Seewaldt, E., Kilpper-Bälz, R., SChleIfer, K.-H., MAGRUM, L., WOESE, C. R., FoX, G. E. \& STACKeBRANDT, E. (1985). The phylogenetic position of Streptococcus and Enterococcus. Journal of General Microbiology 131, 543-551.
Maniatis, T., Fritsch, E. F. \& Sambrook, J. (1982). Molecular Cloning: a Laboratory Manual. Cold Spring Harbor, New York: Cold Spring Harbor Laboratory.

MARMUR, J. (1961). A procedure for the isolation of DNA from microorganisms. Journal of Molecular Biology 3, 208-218.

MeINKOTH, J. \& WAHL, G. (1984). Hybridization of nucleic acids immobilized on solid supports. Analytical Biochemistry 38, 267-284.

Messing, J. (1983). New M13 vectors for cloning. Methods in Enzymology 101, 20-78.

MEssing, J. \& VieIRA, J. (1982). A new pair of M13 vectors for selecting either DNA strand of doubledigest restriction fragments. Gene 19, 269-276.

MEYER, S. A. \& SChleIfER, K. H. (1975). Rapid procedure for the approximate determination of the deoxyribonucleic acid base composition of micrococci, staphylococci, and other bacteria. International Journal of Systematic Bacteriology 25, 383-385.

Meyer, S. A. \& SCHLEIfER, K. H. (1978). Deoxyribonucleic acid reassociation in the classification of coagulase positive Staphylococci. Archives of Microbiology 117, 183-188.

Regensburger, A., LudWig, W., Frank, R., BLÖCKER, H. \& SCHLEIFER, K. H. (1988). Complete nucleotide sequence of a $23 \mathrm{~S}$ ribosomal RNA gene from Micrococcus luteus. Nucleic Acids Research (in the Press).

Sanger, F., Nickler, S. \& Coulson, A. R. (1977). DNA sequencing with chain-terminating inhibitors. Procedings of the National Academy of Sciences of the United States of America 74, 5463-5467.

SChleifer, K. H., LudWig, W., KRaUs, J. \& Festl, H. (1985). Cloned ribosomal ribonucleic acid genes from Pseudomonas aeruginosa as probes for conserved deoxyribonucleic acid sequences. International Journal of Systematic Bacteriology 35, 231-236.

Southern, E. M. (1975). Detection of specific sequences among DNA fragments separated by gel electrophoresis. Journal of Molecular Biology 98, 503-517.

StackebrandT, E. \& Schleifer, K.-H. (1984). Molecular systematics of actinomycetes and related organisms. In Biological, Biochemical and Biomedical Aspects of Actinomycetes, pp. 485-504. Edited by L. Ortiz-Ortiz, L. F. Bojalil \& V. Yakoleff. London: Academic Press.

Stackebrandt, E., Ludwig, W., Schleifer, K. H. \& Gross, H. J. (1981). Rapid cataloging of ribonuclease Tl resistant oligonucleotides from ribosomal RNAs for phylogenetic studies. Journal of Molecular Evolution 17, 227-236.

Woese, C. R., Stackebrandt, E., Macke, T. J. \& Fox, J. E. (1985). A phylogenetic definition of the major eubacterial taxa. Systematic and Applied Microbiology 6, 143-151.

YANNISCH-PERRoN, C., VieIRA, J. \& Messing, J. (1985). Improved M13 phage cloning vectors and host strains: nucleotide sequences of the $\mathrm{M} 13 \mathrm{mp} 18$ and pUC19 vectors. Gene 33, 103-119. 